\title{
Analisis Sistem Pemilihan dan Daur Ulang Sampah Rumah Tangga di Daerah Perkotaan Menggunakan Pendekatan Life Cycle Assessment (LCA)
}

\author{
Yosef Adicita* dan Anshah Silmi Afifah
}

Jurusan Teknik Lingkungan; Fakultas Teknik , Universitas Universal;

\begin{abstract}
ABSTRAK
Secara umum sistem pengelolan sampah padat rumah tangga yang ada di Kota Batam saat ini adalah dari sumber, pewadahan, pengumpulan, pemindahan, pengangkutan dan pemrosesan akhir. Salah satu proses yang dapat berpengaruh pada sistem pengelolaan sampah adalah proses daur ulang. Proses daur ulang belum dilakukan dengan baik dan maksimal karena dari setiap rumah tangga, sampah kemudian dikumpulkan dengan cara digabungkan tanpa memikirkan komponennya. Kurangnya proses pemisahan sampah berdasarkan komposisinya dapat berpengaruh pada lingkungan karena proses pengelolaan dan pengolahan tidak dilakukan dengan semestinya terutama pada saat pandemi seperti ini. Penelitian ini bertujuan untuk menentukan potensi dampak lingkungan dengan membandingkan empat skenario daur ulang yang berhubungan dengan proses pemisahan sampah menggunakan life cycle assessment (LCA). Penelitian akan dibagi menjadi lima tahapan yaitu tahapan pengumpulan data sekunder, penentuan skenario pemisahan sampah dan daur ulang, life cycle assessment (LCA) pengolahan dan analisis data menggunakan perhitungan IPCC dan kesimpulan serta rekomendasi. Hasil menunjukan bahwa skenario pertama yaitu pemisahan dilakukan 0,002\% dari total sampah Kota Batam memiliki persentase Global Warming Potential (GWP) tertingi sebesar 36,82\% dengan $\mathrm{CH}_{4}$ merupakan potensi senyawa tertinggi yang mempengaruhi persentase GWP.
\end{abstract}

Kata kunci: Batam, GWP, LCA, Sampah rumah tangga

\begin{abstract}
In general, the existing municipal solid waste management system in Batam City today is from the source, storage, collection, transfer, transportation and final disposal. One of the processes that can affect the waste management system is recycling. The recycling process has not been carried out optimally and adequately because of every household. Waste is then collected by combining it without thinking about the components. The lack of a waste separation process based on its composition can affect the environment because the management and processing process is not carried out properly, especially during a pandemic like this. This study aims to determine the potential environmental impact by comparing four recycling scenarios related to the waste separation process using a life cycle assessment (LCA). This study was divided into five steps first collected secondary data, determined waste separated and recycling scenario, data analyzed using IPCC, conclusion and recommendation. The results show that the first scenario, i.e. separation is done $0.002 \%$ of the total waste in Batam City, has the highest Global Warming Potential (GWP) percentage of 36.82\%, with CH4 being the highest potential compound that affects the GWP percentage
\end{abstract}

Keywords: Municipal solid waste, LCA, GWP, Batam

Citation: Adicita, Y. dan Afifah, A.S. (2022). Analisis Sistem Pemilihan dan Daur Ulang Sampah Rumah Tangga di Daerah Perkotaan Menggunakan Pendekatan Life Cycle Assessment (LCA. Jurnal Ilmu Lingkungan, 20(2), 406-413, doi:10.14710/jil.20.2.406-413

\section{Latar Belakang}

Secara umum, masyarakat baik yang berada di daerah perkotan maupun pedesaan di Indonesia masih menggabungkan semua komponen sampah yang dihasilkan termasuk sampah yang berbahaya bagi lingkungan dan Kesehatan. Sampah rumah tangga yang berbahaya relatif kecil, berkisar antara $0,3 \%-0,5 \%$ oleh setiap rumah tangga tetapi hal ini tetap perlu dilakukan pengelolaan dengan baik dan menyeluruh (Fikri et al., 2015, 2018). Rata- rata masyarakat masih tidak menyadari bahwa beberapa jenis sampah yang dihasilkan adalah jenis sampah berbahaya yang kandungan kimianya hampir sama dengan limbah industri dan dapat berpotensi mencemari lingkungan seperti baterai, kosmetik yang sudah kadaluarsa dan jenis sampah lainnya yang melibatkan bahan kimia. Selain itu juga, beberapa sampah yang dihasilkan tidak biodegradable (Fikri et al., 2018) . Hal ini sejalan dengan penelitian yang dilakukan di Mexico, kategori sampah rumah tangga yang berbahaya yang sering

\footnotetext{
*Penulis korespondensi: yosef.adicita@uvers.ac.id
} 
digunakan sehari-hari seperti kemasan detergen yang masih ada sisa detergennya, baterai, obat-obatan yang sering dibuang begitu saja ke tempat sampah tanpa dipisahkan dan diberikan penanda, kosmetik, elektronik bahkan kepingan cd baik vcd maupun dvd (Delgado et al., 2007). Jenis sampah kota yang biasa dihasilkan oleh kota-kota di Indonesia adalah sampah organik berupa sisa makanan dan sampah anorganik seperti kertas, plastik, pakaian, karet, kulit dan logam. Sampah ini berasal dari kegiatan sehari-hari dengan komposisi sampah yang dihasilkan dipengaruhi oleh tingkatan sosial-ekonomi penduduk, luas pemukiman dan musim di daerah tersebut (Ariyani et al., 2019). Pemisahan sampah rumah tangga di beberapa negara biasanya dilakukan untuk mengklasifikasikan jenis sampah yang nantinya berguna pada saat dilakukannya proses pengolahan selanjutnya. Seperti di Jepang, pemisahan jenis sampah rumah tangga ini dikhusukan untuk mengelompokan sampah yang dapat diinsinerasi dan sampah yang tidak dapat diinsenerasi. Sampah yang tidak dapat diinsinerasi kemudian dilakukan jenis pengolahan lainnya seperti daur ulang. Sedangkan di Jerman, pemisahan sampah dilakukan memang untuk mengelompokan sampah yang dapat didaur ulang dan tidak dapat di daur ulang, serta sampah yang dapat dikompos. US menfokuskan kepada jenis sampah seperti kertas, kaca, dan plastik untuk dapat di daur ulang (Yuan et al., 2020)

Berdasarkan penelitian yang dilakukan (Fikri et al., 2018) karakteristik sampah rumah tangga di Kecamatan Perudungan, Semarang, selain sampah organik yang berasal dari sisa makanan, terdapat sampah yang berbahaya yaitu 78\% sampah yang infeksius seperti popok, perban, kondom dan bekas jarum suntik. Penelitian lainnya mengelompokkan sampah menjadi beberapa kelompok seperti sampah yang dapat didaur ulang, dapat dikompos, dapat dibakar dan sampah berbahaya dengan membuat kategori sampah berdasarkan jenis materialnya seperti plasik, kertas, buangan dari dapur, karet dan kulit, kain, logam, rumput dan kayu, kaca, keramik, dan jenis sampah lainnya (Thanh et al., 2010). Kategori sampah ini akan berpengaruh pada komposisi kimianya seperti produksi metannya, nitrogen $(\mathrm{N})$, fosfor $(\mathrm{P})$ dan kalium (K) (Bernstad et al., 2011).

Selain itu juga, penelitian lainnya juga menyebutkan bahwa sampah dapat dikelompokan menjadi jenis sampah basah yang terdiri sisa makanan dan sampah kebun, plastik berupa plastik HDPE, LDPE dan PET serta campuran, kemudian kertas dan kardus yang terdiri dari office paper, koran, majalah, buku, papan bahan kertas, kertas campuran. Kategori lainnya adalah popok, kabel, kayu, b3, kain, kaca, karet, alumunium, baja, logam. Kulit, sterofoam, dan lainnya yang tidak termasuk ke dalam kategori (Aziz \& Febriardy, 2016).

Timbulan sampah di Kota Batam mengalami peningkatan setiap tahunnya. Berdasarkan data dinas kebersihan dan pertamanan (DKP) Kota Batam, timbulan sampah meningkat hingga dua kali lipat selama kurang lebih 8 tahun yaitu dari 208.000 menjadi 432.000 pada tahun 2006 hingga 2014, dengan pertumbuhan penduduk dari 95000 jiwa menjadi 114000 jiwa. Pada tahun 2019, timbulan sampah di Kota Batam sudah mencapai 1000 ton/hari dengan jumlah penduduk adalah 137000 jiwa. Timbulan ini akan terus meningkat seiring dengan peningkatan jumlah penduduk kota Batam (Adicita et al., 2020). Secara umum sistem pengelolan sampah yang ada di Kota Batam saat ini adalah dari sumber, pewadahan, pengumpulan, pemindahan, pengangkutan dan pemrosesan akhir. Salah satu proses yang dapat berpengaruh pada sistem pengeloaan sampah adalah proses daur ulang. Proses daur ulang belum dilakukan dengan baik dan maksimal karena dari setiap rumah tangga, sampah kemudian dikumpulkan dengan cara digabungkan tanpa memikirkan komponennya. Kurangnya proses pemisahan sampah berdasarkan komposisinya dapat berpengaruh pada lingkungan karena proses pengelolaan dan pengolahan tidak dilakukan dengan semestinya.

Beberapa penelitian sudah banyak dilakukan tentang evaluasi dan penilaian dampak lingkungan dari proses pemisahan, pengelompokan dan pengolahan sampah. Penilaian dan evaluasi dampak lingkungan dari hubungan antara pemisahan sampah dengan proses daur ulang yang dilakukan. Ditetapkan 3 jenis skenario yaitu pemisahan sampah yang kurang optimal, masih ada yang pemisahan yang salah kategori. Skenario kedua adalah pemisahan sampah dilakukan dengan optimal dengan tidak adanya kesalahan pengelompokan kategori, dan skenario terakhir adalah tidak adanya pemisahan sampah. Semua sampah diolah menggunakan insinerasi. Hasil penelitiannya menunjukan bahwa skenario dua dapat memberikan kontribusi dalam mengurangi dampak lingkungan seeperti eutrofikasi, asidifikasi, pembetukan fotokimia hinga dua kali lipat dibandingkan dengan tidak dilakukannya pemisahan (Bernstad et al., 2011).

Penelitian lainnya menunjukan bahwa manajemen persampahan yang terintegrasi dimulai dengan mengklasifikasikan dan memisahkan sampahnya lebih ramah lingkungan dibandingkan dengan tidak mengklasifikasikannya, semakin detail dalam mengklasifikasikannya, semakin kecil dampak pengolahan dan pengelolaan sampah terhadap lingkungan. Pengolahan dan pengelolaan sampah yang dilakukan dengan cara memisahkan sampah terlebih dahulu sebelum dikumpulkan dapat mengurangi gas rumah kaca hingga 23\% (Dong et al., 2013). Sedangkan penelitian yang dilakukan di Hangzhou, China menunjukan bahwa memisahkan sampah di setiap rumah tangga dapat membantu menurunkan dampak lingkungan sekitar 30\% untuk global warming, 18\% untuk asidifikasi, 28\% untuk eutrofikasi dan 29\% untuk pembentukan ozon fotokimia (Xu et al., 2017).

Penelitian ini bertujuan untuk menentukan potensi dampak lingkungan dengan membandingkan beberapa skenario daur ulang yang berhubungan dengan proses 
pemisahan sampah menggunakan pendekatan LCA. Pada penelitian ini akan dirumuskan beberapa skenario kemudian pada tahap kedua dari LCA yaitu life cycle inventory (LCI) akan dilakukan pengembangan model dengan memperhatikan karakterstik kimia sampah dalam penentuan dampak lingkungan.

\section{Metode Penelitian}

\subsection{Tahapan Penelitian}

Penelitian akan dibagi menjadi lima tahapan yaitu tahapan pengumpulan data sekunder, penentuan skenario pemisahan sampah dan daur ulang, life cycle assessment (LCA) pengolahan dan analisis data dan kesimpulan serta rekomendasi. Data sekunder diperoleh dari database dinas terkait. Penentuan implementasi skenario dilakukan dengan cara merumuskan dari data primer dan sekunder serta studi literatur. Sedangkan untuk LCA dilakukan berdasarkan ISO 1440: 2006. Life cycle impact model sebagai bentuk tahap analisis data dilakukan dengan perhitungan manual menggunakan Microsoft excel yang mengacu pada metode untuk analisis dampak.

\subsection{Tahap Identifikasi Awal}

Tahap identifikasi awal merupakan tujuan dan ruang lingkup studi pendekatan LCA. Tujuan dari penelitian ini adalah membandingkan beberapa skenario daur ulang yang berhubungan dengan proses pemisahan sampah menggunakan pendekatan life cycle assessment (LCA) di Kota Batam. Ruang lingkup penelitian ini adalah gate to gate, mulai dari sampah dihasilkan sampai akhir perlakukan sampah dan mengacu pada data yang diperoleh dengan penilaian dampak meliputi pemisahan dan pengolahan sampah di tempat pemrosesan akhir (TPA). Unit fungsi dari sebagai basis perhitungan dalam studi LCA ini adalah 1 kg sampah rumah tangga perkotaan di Kota Batam yang dikelola. Batasan sistem penelitian ini secara umum dapat dilihat pada Gambar 2. Pada penelitian ini akan ditetapkan beberapa skenario yang akan dibandingkan yaitu:

a. Skenario 1: pemisahan dilakukan 0,002\% dari total sampah Kota Batam (Gambar 3a).

b. Skenario 2: Pemisahan dilakukan $100 \%$ dari total sampah dengan sampah plastik dikategorikan menjadi termoset dan termoplastik (Gambar 3b)

c. Skenario 3: Pemisahan dilakukan 100\% dari total sampah tetapi daur ulang hanya dilakukan untuk sampah kertas-karton dan kaca (Gambar 3c)

d. Skenario 4: idak dilakukan pemisahan sama sekali, sampah rumah tangga langsung diolah di TPA dengan menggunakan $50 \%$ sanitary landfill dan $50 \%$ insenerasi (Gambar 3d).

Beberapa asumsi dan batasan lainnya (Gambar 2) ditetapkan pada ke empat skenario tersebut karena keterbatasan data seperti transportasi tidak dimasukan dalam perhitungan LCA, skenario 1 berdasarkan kondisi saat ini di Kota Batam dan skenario 4 berdasatkan hasil penelitian sebelumnya pada tahun 2020 mengenai PROMETHEE analisis untuk ranking pengolahan sampah yang ideal di Kota Batam, pengolahan akhir di TPA yang ideal adalah 50\% sanitary landfill dan 50\% insenerasi. Selain itu juga, output yang dihitung yang kemudian dilakukan analisis menggunakan pendekatan LCA hanya sebatas emisi ke atmosfer yaitu kategori dampak climate change.

\subsection{Timbulan dan komposisi sampah Kota Batam}

Berdasarkan dinas lingkungan hidup dan kehutanan (DLHK) Kota Batam dan sistem informasi pengelolaan sampah nasional (SIPSN), jumlah timbulan sampah rumah tangga setiap harinya mencapai \pm 1.458 $\mathrm{kg} /$ hari pada tahun 2019-2020 dengan komposisi dapat dilihat pada Gambar 1. Data komposisi mengacu pada batasan identifikasi yaitu sisa makanan, kertas, plastik dan kaca.

\subsection{Life Cycle Inventory (LCI)}

Life cycle inventory diterapkan pada data seluruh data yang terkumpul di setiap input dan ouput skenario yang dirumuskan. Prosedur analisis inventori ini disederhanakan berdasarkan ISO 14044. Perhitungan analisis inventori ini dilakukan dengan manual menggunakan Microsoft excel dengan pertimbangan dan asumsi-asumsi yang sudah disebutkan pada bagian tahap identifikasi awal.

Perhitungan beban pencemaran dilakukan hanya sebatas pada pencemaran udara karena keterbatasan data yang diperoleh. Inventarisasi emisi menggunakan Tier 1 yang mengacu pada IPCC guildine tahun 2006 dimana Tier 1 menggunakan data aktivitas dan faktor emisi yang umum. Hal ini menimbang karena data khusus Indonesia belum ada.

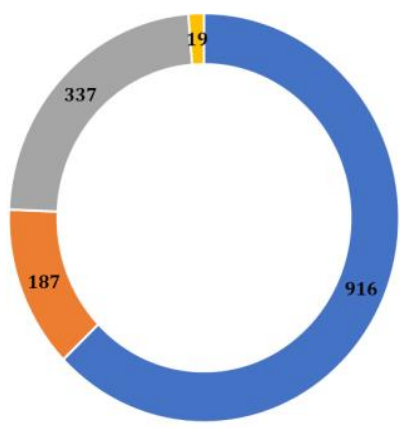

- Sisa Makanan (kg/hari) " Kertas-Karton (kg/hari) " Plastik(kg/hari) " Kaca(kg/hari)

Gambar 1 Timbulan dan komposisi sampah Kota Batam tahun 2019-2020 


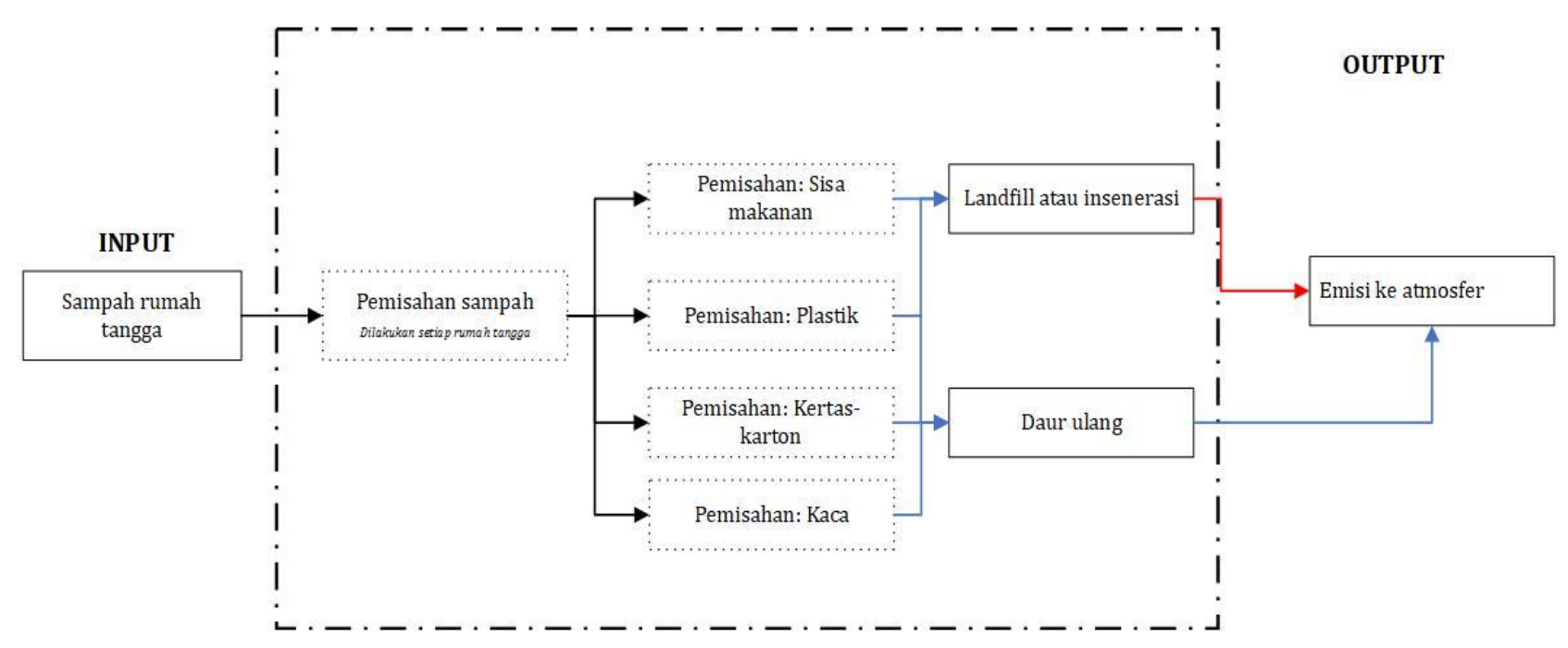

Gambar 2 Batasan sistem model

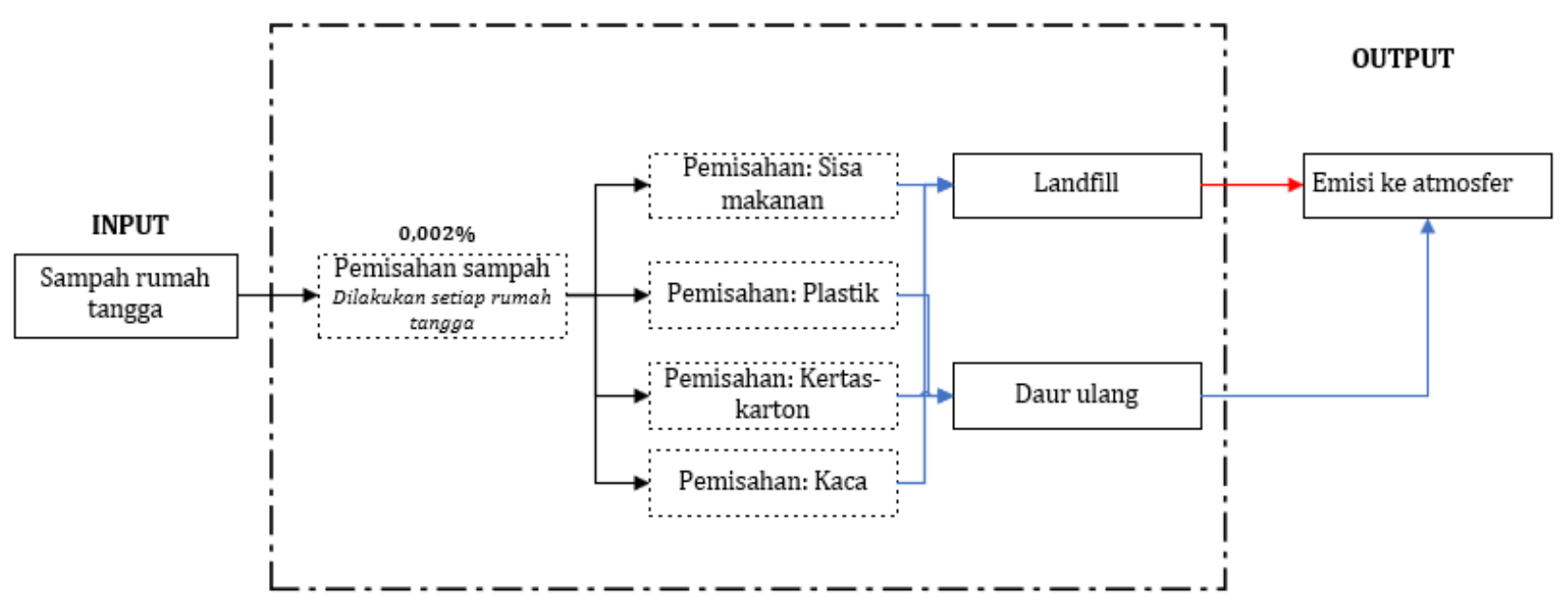

(a)

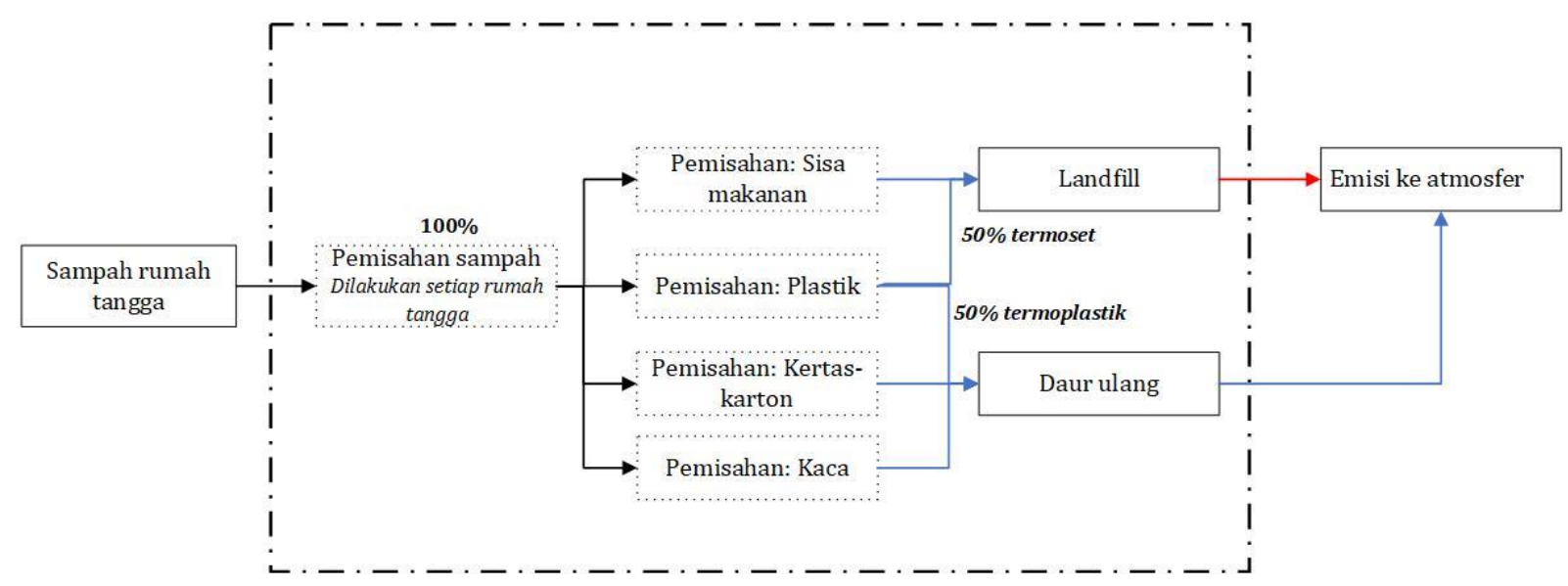

(b) 


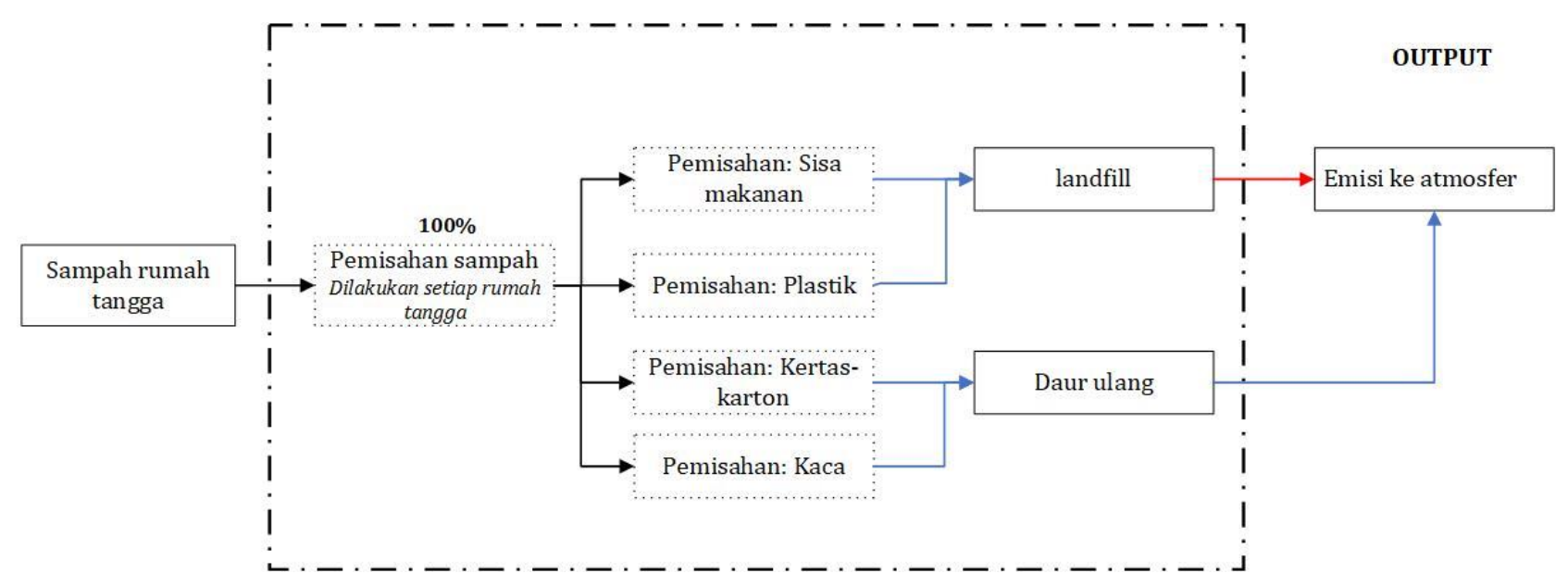

(c)

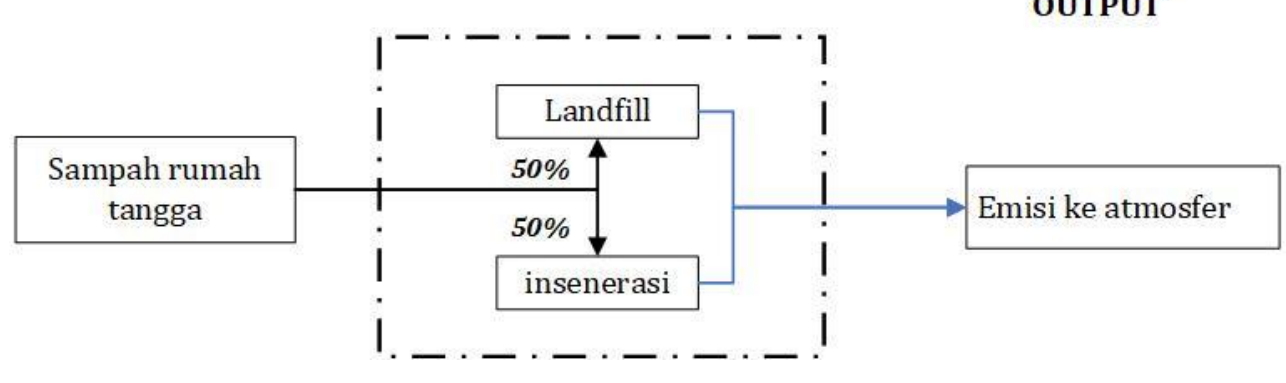

(d)

Gambar 3 a) skenario 1, b) skenario 2, c) skenario 3 dan d) skenario 4

Tabel 1. Distrbusi sampah diolah pada masing-masing skenario sebagai

\begin{tabular}{lcccc}
\hline \hline \multirow{2}{*}{ Jenis pengolahan sampah } & \multicolumn{4}{c}{ Jumlah sampah setiap skenario (ton/tahun) } \\
\cline { 2 - 5 } & $\mathrm{S} 1$ & $\mathrm{~S} 2$ & $\mathrm{~S} 3$ & $\mathrm{~S} 4$ \\
\hline Landfill & 528 & 334 & 395,82 & 263,99 \\
Insinerasi & 0 & 0 & 0 & 263,99 \\
Daur Ulang & 0,01056 & 194 & 132 & 0 \\
\hline
\end{tabular}

a. Data input

Tabel 1 menunjukan distribusi sampah yang diolah pada masing-masing skenario dihitung berdasarkan data timbulan dan komposisi sampah Kota Batam pada tahun 2019-2020. Distribusi ini sebagai data inventori input untuk perhitungan potensi GRK.

\section{b. Data Output}

Output dari setiap skenario yaitu emisi gas rumah kaca (GRK) yang terdiri dari $\mathrm{CO}_{2}, \mathrm{CH}_{4}$ dan $\mathrm{N}_{2} \mathrm{O}$ dihitung menggunakan persamaan yang mengacu pada IPCC
2006. Perhitungan dilakukan untuk menentukan potensi pemanasan global (GWP) yang dihasilkan oleh setiap skenario. Kemudian hasil perhitungan tersebut dilakukan perbandingan perhitungan menggunakan faktor emisi menggunakan standar CML baseline. Perhitungan $\mathrm{CH}_{4}$ dan $\mathrm{CO}_{2}$ dari landfill dilakukan menggunakan persamaan (1), (2) dan (3). $\mathrm{N}_{2} \mathrm{O}$ tidak dilakukan perhitungan karena berdasarkan IPCC 2006 diasumsikan bahwa $\mathrm{N}_{2} \mathrm{O}$ yang dihasilkan oleh landfill tidak terlalu signifikan.

$$
\text { Emisi } \mathrm{CH}_{4}(\mathrm{Gg} / \text { tahun })=\left[\left(M S W_{T} \times M S W_{F} \times L_{0}-R\right] \times(1-O X)\right.
$$

$\mathrm{MSW}_{\mathrm{T}}$ merupakan timbulan sampah yang dihasilkan $\left(\mathrm{Gg} /\right.$ tahun), $\mathrm{MSW}_{\mathrm{F}}$ adalah fraksi timbulan sampah yang dihasilkan yang dibuang di landfill, $L_{0}$ merupakan potensi metan yang dihasilkan diperoleh dari persamaan (2). R merupakan $\mathrm{CH} 4$ recovery. Pada penelitian ini, $\mathrm{R}$ yang digunakan adalah 0 yang merupakan default number dari tier 1 dan OX adalah faktor oksidasi dimana pada penelitian ini, OX yang 
digunakan adalah 0 yang merupakan default number tier 1

$$
L_{0}=\left[M C F \times D O C \times D O C_{F} \times F \times 16 / 12\right]
$$

Dimana MCF adalah koreksi metana untuk dekomposisi aerobik, menggambarkan bagian sampah yang akan terdekomposisi dalam kondisi aerobik (sebelum kondisi anerobik terjadi) dalam tahun pemrosesan sampah. penelitian ini menggunakan 0,8 karena diasumsikan sanitary yang dilakukan tidak dikelola dengan baik. Sedangkan DOC merupakan fraksi degradasi organik karbon (Gg C/Gg sampah) dan $D O C_{F}$ merupakan fraksi DOC yang terdekomposisi dalam kondisi anaerobik. $D O C_{F}$ untuk tier 1 adalah 0,77 yang merupakan default number. F adalah raksi (\%- volume) timbulan gas metan pada landfill, nilai $\mathrm{F}$ default berdasarkan IPCC adalah 50\%. 16/12 adalah rasio berat molekul $\mathrm{CH}_{4} / \mathrm{C}$ ( $\mathrm{Gg} \mathrm{CH}_{4} / \mathrm{Gg}$ sampah). Sedangkan untuk perhitungan emisi $\mathrm{CO}_{2}$ dilakukan berdasarkan persamaan (3), dimana $44 / 12=$ rasio berat molekul CO2/C.

Untuk DOC yang sudah dihitung berdasarkan komposisi sampah dapat dilihat pada tabel 2 . Sedangkan untuk perhitungan emisi $\mathrm{CO}_{2}$, dan $\mathrm{N}_{2} \mathrm{O}$ dari insinerasi dihitung penggunakan persamaan (4) dan persamaan (5) yang mengacu pada IPCC 2006. Sedangkan $\mathrm{CH}_{4}$ tidak dilakukan perhitungan karena berdasarkan IPCC 2006 diasumsikan bahwa $\mathrm{CH}_{4}$ yang dihasilkan oleh landfill tidak terlalu signifikan.

$$
\begin{gathered}
\text { Emisi } \mathrm{CO}_{2}(G g / \text { tahun })=44 / 12 \times M S W \times D O C \times D O C_{F} \times(1-M C F) \\
\text { Emisi } \mathrm{CO}_{2}(G g / \text { tahun })=44 / 12 \times M S W \times D O C \times D O C_{F} \times(1-M C F) \\
\text { Emisi } \mathrm{N}_{2} O\left(G g / \text { tahun }_{1}\right)=\sum i\left(I W_{i} \times E F_{i}\right) \times 10^{-6}
\end{gathered}
$$

Tabel 2. DOC untuk setiap skenario

\begin{tabular}{cc}
\hline \hline Skenario & DOC (Gg C/Gg sampah) \\
\hline S1 & 0,0211 \\
S2 & 0,0195 \\
S3 & 0,0195 \\
S4 & 0,0053 \\
\hline
\end{tabular}

$\mathrm{IW}_{\mathrm{i}}$ merupakan jumlah sampah yang diinsinerasi dengan tipe i dan Sedangkan untuk penilaian dan $\mathrm{EF}_{\mathrm{i}}$ merupakan Agregat emisi faktor untuk $\mathrm{N}_{2} \mathrm{O}$ tipe sampah i. Pada penelitian ini diasumsikan jenis insinerasi yang digunakan adalah continuous yaitu $0,01 \mathrm{~kg} \mathrm{~N}_{2} \mathrm{O} / \mathrm{Gg}$ sampah. Data inventori berupa input

\begin{tabular}{|c|c|c|c|c|c|}
\hline \multirow{2}{*}{ Input/ouput } & \multicolumn{4}{|c|}{ Skenario } & \multirow{2}{*}{ Unit } \\
\hline & 1 & 2 & 3 & 4 & \\
\hline \multicolumn{6}{|c|}{ sampah di setiap pengolahan } \\
\hline sisa makanan & 27866,50 & 27866,50 & 27866,50 & 27866,50 & $\mathrm{~kg} / \mathrm{bulan}$ \\
\hline kertas & 5687,04 & 5687,04 & 5687,04 & 5687,04 & $\mathrm{~kg} / \mathrm{bulan}$ \\
\hline plastik & 10236,68 & 10236,68 & 10236,68 & 10236,68 & $\mathrm{~kg} / \mathrm{bulan}$ \\
\hline kaca & 207,58 & 207,58 & 207,58 & 207,58 & $\mathrm{~kg} / \mathrm{bulan}$ \\
\hline \multicolumn{6}{|l|}{ Emisi } \\
\hline $\mathrm{CH} 4$ & 100,514214 & 37,39966016 & 52,40002365 & 6,282389666 & $\mathrm{~kg} / \mathrm{bulan}$ \\
\hline $\mathrm{CO} 2$ & 523,5482045 & 307,5647882 & 364,05628 & 557,9831272 & $\mathrm{~kg} / \mathrm{bulan}$ \\
\hline $\mathrm{N} 2 \mathrm{O}$ & 0 & 0 & 0 & 0,000290371 & $\mathrm{~kg} / \mathrm{bulan}$ \\
\hline
\end{tabular}
dan output dari empat skenario yang dirumuskan dapat dilihat pada tabel 3 .

Tabel 3. Data inventaris input dan output 


\section{Hasil dan Pembahasan}

Potensi pemanasan global dihitung menggunakan metode karakteristik CML Baseline dengan menggunakan data GWP100. Satuan dari potensi ini adalah $\mathrm{CO}_{2}$.equivalent. hasil perhitungan dapat dilihat pada tabel 4 . CF merupakan faktor karakteristik dari senyawa terhadap kategorai dampak. CF digunakan untuk menghitung hasil indicator untuk kategori dampak dimana pada Tabel 4 adalah kategori dampak untuk potensi pemanasa global CF untuk model CML baseline adalah 1 untuk $\mathrm{CO}_{2}, 25$ untuk $\mathrm{CH}_{4}$ dan 298 untuk $\mathrm{N}_{2} \mathrm{O}$. Berdasarkan perhitungan yang dilakukan menggunakan model CML baseline untuk GWP, skenario 1 yaitu pemisahan sampah dilakukan hanya $0,002 \%$ sesuai dengan situtasi di Kota Batam saat ini (Gambar 4). $\mathrm{CH}_{4}$ merupakan senyawa yang berkontribusi terbesar pada GWP untuk ke empat skenario ini. CH4 berasal dari sanitary landfill. Berdasarkan penelitian yang dilakukan oleh Lando dkk, pada tahun2021, $\mathrm{CH}_{4}$ yang dihasilkan oleh sanitary landfill di Kota Makasar mencapai 2,240 $\mathrm{Gg} /$ tahun atau sekitar $56 \times 10^{6} \mathrm{~kg} \mathrm{CO} 2$ eq untuk $237851884 \mathrm{~kg}$ sampah pada tahun 2016.

Penelitian lainnya juga menyebutkan bahwa $\mathrm{CH}_{4}$ yang berasal dari sanitary landfill jika tidak diolah dengan baik dapat mencapai $4,87 \mathrm{Gg} /$ tahun atau setara dengan $147 \times 10^{9} \mathrm{~kg} \mathrm{CO}_{2}$ eq (Dimishkovska et al., 2019) (Sohoo et al., 2021). Potensi senyawa gas rumah kaca secara keseluruhan untuk ke empat skenario dapat dilihat pada Gambar 5.

Berdasarkan Gambar 6 dapat dilihat bahwa senyawa $\mathrm{CH}_{4}$ menyumbang $83,434 \%$ untuk GWP pada ke empat skenario pengelolaan sampah di Kota Batam. Skenario satu hingga skenario empat masing-masing menggunakan pengolahan akhir menggunakan sanitary landfill. Jika sanitary landfill yang digunakan diasumsikan tidak dikelola dengan baik.

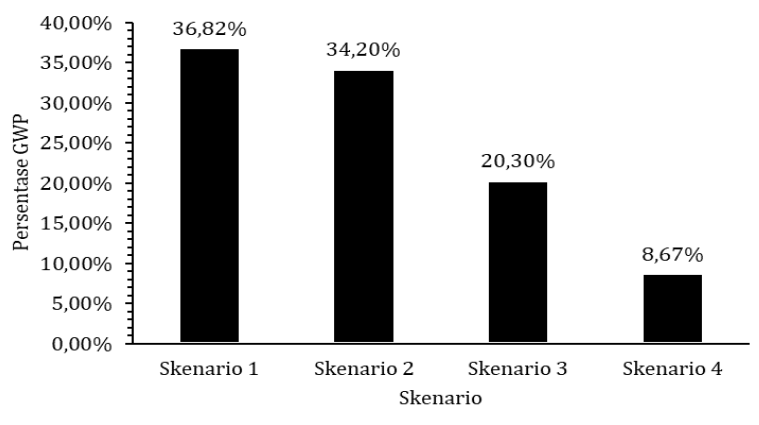

Gambar 4 Persentase GWP pada setiap skenario pengelolaan sampah di kota Batam

$\mathrm{CH}_{4}$ dihasilkan oleh bakteri dekomposisi untuk materi organik di dalam landfill tersebut. Semakin besar materi organic di dalam kandungan sampah yang diolah menggunakan landfill maka semakin tinggi konsentrasi $\mathrm{CH}_{4}$. Komposisi sampah terbanyak yang dikelola dan diolah menggunakan sanitary landfill ini adalah sisa makanan yang mengandung banyak materi organik (Dimishkovska et al., 2019) (Suryawan et al., 2021).

Sedangkan untuk daur ulang, akan berpotensi menghasilkan emisi seperti $\mathrm{CH}_{4}$ namun tidak terlalu signifikan dibandingkan dengan pengolahan sampah secara keseluruhan menggunakan landfill. Perhitungan dilakukan dengan menggunakan faktor emisi $0,535 \mathrm{~kg}$ $\mathrm{CO}_{2}$ eq yang mengacu pada penelitian Turner dkk pada tahun 2015 sehingga diperoleh hasil bahwa potensi GWP yang dapat dilihat pada Gambar 7, jika dilakukan proses daur ulang adalah skenario 3 yaitu $132 \mathrm{~kg} \mathrm{CO}_{2}$ eq Setiap hasil perhitungan potensi GWP daur ulang ini telah ditambahkan pada Tabel 4 .

Tabel 4. Hasil perhitungan potensi pemanasan global menggunakan CML baseline

\begin{tabular}{|c|c|c|c|c|c|}
\hline \multirow{3}{*}{ Senyawa } & \multirow{3}{*}{ CF } & \multicolumn{4}{|c|}{ Skenario } \\
\hline & & \multicolumn{4}{|c|}{ kg CO2 equivalent } \\
\hline & & Skenario 1 & Skenario 2 & Skenario 3 & Skenario 4 \\
\hline $\mathrm{CO} 2$ & 1 & 6282,578454 & 3690,777459 & 4368,675359 & 6695,797526 \\
\hline $\mathrm{CH} 4$ & 25 & 30154,26419 & 30154,26419 & 15720,00709 & 1884,7169 \\
\hline N2O & 298 & 0 & 0 & 0 & 1,038366454 \\
\hline
\end{tabular}

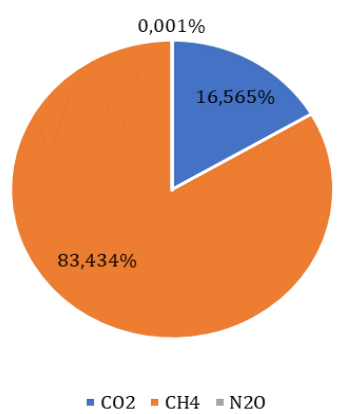

Gambar 5 Potensi senyawa gas rumah kaca secara keseluruhan untuk ke empat skenario 


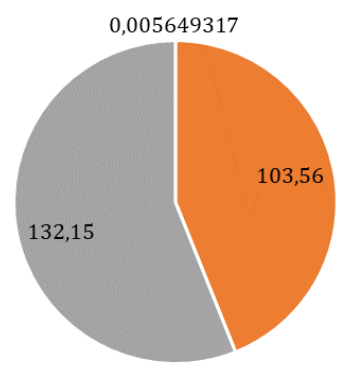

- $\mathrm{kg}$ CO2 eq Skenario 1 " $\mathrm{kg}$ CO2 eq skenario $2 \approx \mathrm{kg}$ CO2 eq Skenario 3

Gambar 6 Potensi GWP untuk daur ulang setiap skenario

Berdasarkan Gambar 6 dapat dilihat bahwa daur ulang juga memiliki potensi GWP tetapi tidak sebesar pengelolaan dengan menggunaan landfill atau insinerasi. Hasil perhitungan menunjukan bahwa bahwa pemisahan sampah yang dilakukan harus diiringi dengan pemilihan pengolahan sampah di tempat pemrosesan terakhir sampah agar dapat menurunkan potensi GWP. Skenario 4 tidak dihitung karena tidak dilakukan daur ulang sama sekali.

\section{Kesimpulan}

Berdasarkan perhitungan yang dilakukan, mengenai potensi GWP pada setiap skenario pengelolaan untuk sampah rumah tangga di kota Batam, skenario pertama memiliki persentase GWP tertingi sebesar $36,82 \%$ dengan $\mathrm{CH}_{4}$ merupakan potensi senyawa tertinggi yang mempengaruhi persentase GWP. Penelitian ini hanya sebatas menghitung potensi sehingga perlu dilakukan pengkajian lebih lanjut seperti pengkajian potensi dampak secara lengkap untuk memastikan bahwa hasil penelitian dapat diterapkan di Kota Batam. Pemisahan sampah juga dapat mengurangi potensi GWP seperti skenario dua dan skenario tiga.

\section{DAFTAR PUSTAKA}

Adicita, Y., Apritama, M. R., \& Afifah, A. S. (2020). Multi Criteria Decision Making pada Strategi Pengolahan Sampah Padat Perkotaan. JTERA (Jurnal Teknologi Rekayasa), 5(2), 191. https://doi.org/10.31544/jtera.v5.i2.2020.191-200

Ariyani, S. F., Putra, H. P., Kasam, Damanhuri, E., \& Sembiring, E. (2019). Evaluation of Waste Management in Piyungan Landfill, Bantul Regency, Yogyakarta, Indonesia. MATEC Web of Conferences, 280, 05018. https://doi.org/10.1051/matecconf/201928005018

Aziz, R., \& Febriardy, F. (2016). Analisis Sistem Pengelolaan Sampah Perkantoran Kota Padang Menggunakan Metode Life Cycle Assessment. Jurnal Dampak, 13(2), 60. https://doi.org/10.25077/dampak.13.2.6067.2016

Bernstad, A., La Cour Jansen, J., \& Aspegren, H. (2011). Life cycle assessment of a household solid waste source separation programme: A Swedish case study. Waste Management and Research, 29(10), 1027-1042. https://doi.org/10.1177/0734242X11406170

Delgado, O. B., Ojeda-Benítez, S., \& Márquez-Benavides, L. (2007). Comparative analysis of hazardous household waste in two Mexican regions. Waste Management. https://doi.org/10.1016/j.wasman.2006.03.022

Dimishkovska, B., Berisha, A., \& Lisichkov, K. (2019). Estimation of methane emissions from Mirash municipal solid waste sanitary landfill, differences between IPPC 2006 and LandGEM method. Journal of Ecological Engineering, 20(5), 35-41. https://doi.org/10.12911/22998993/105332

Dong, J., Ni, M., Chi, Y., Zou, D., \& Fu, C. (2013). Life cycle and economic assessment of source-separated MSW collection with regard to greenhouse gas emissions: A case study in China. Environmental Science and Pollution Research. https://doi.org/10.1007/s11356013-1569-1

Fikri, E., Purwanto, P., \& Sunoko, H. R. (2018). Characteristics and Generation of Household Hazardous Waste (HHW) in Semarang City Indonesia. E3S Web of Conferences. https://doi.org/10.1051/e3sconf/20183109026

Lando, A. T., Rahim, I. R., Sari, K., Djamaluddin, I., Arifin, A. N., \& Sari, A. M. (2021). Estimation of methane emissions from municipal solid waste landfill in makassar city based on ipcc waste model. IOP Conference Series: Earth and Environmental Science, 841(1). https://doi.org/10.1088/1755-1315/841/1/012002

Sohoo, I., Ritzkowski, M., Sohu, Z. A., Cinar, S. Ö., Chong, Z. K., \& Kuchta, K. (2021). Estimation of methane production and electrical energy generation from municipal solid waste disposal sites in Pakistan. Energies, 14(9). https://doi.org/10.3390/en14092444

Suryawan, I. W. K., Rahman, A., Septiariva, I. Y., Suhardono, S., \& Wijaya, I. M. W. (2021). Life Cycle Assessment of Solid Waste Generation During and Before Pandemic of Covid-19 in Bali Province. Journal of Sustainability Science and Management, 16(1), 11-21. https://doi.org/10.46754/jssm.2021.01.002

Thanh, N. P., Matsui, Y., \& Fujiwara, T. (2010). Household solid waste generation and characteristic in a Mekong Delta city, Vietnam. Journal of Environmental Management. https://doi.org/10.1016/j.jenvman.2010.06.016

Turner, D. A., Williams, I. D., \& Kemp, S. (2015). Greenhouse gas emission factors for recycling of source-segregated waste materials. Resources, Conservation and Recycling, 105(November), 186-197. https://doi.org/10.1016/j.resconrec.2015.10.026

$\mathrm{Xu}$, L., Ling, M., Lu, Y., \& Shen, M. (2017). Understanding household waste separation behaviour: Testing the roles of moral, past experience, and perceived policy effectiveness within the theory of planned behaviour. Sustainability (Switzerland), 9(4) https://doi.org/10.3390/su9040625

Yuan, Y., Li, T., \& Zhai, Q. (2020). Life cycle impact assessment of garbage-classification based municipal solid waste management systems: A comparative case study in China. International Journal of Environmental Research and Public Health. https://doi.org/10.3390/ijerph17155310 